Cardiologia 1966;48:3-4

\title{
Pierre W. Duchosal
}

Le nora Pierre W. Duchosal a depuis longtemps dépassé les frontières de Geneve et de la Suisse. Ses nombreux travaux sur Гélectro-, la vecto- et la phonocardiographie sont devenus des " classiques » cites et consultés dans le monde entier. Nous sommes heureux à $\Gamma$ occasion de son 60 e anniversaire de lui dédier ce 